\title{
PENGEMBANGAN MODEL EVALUASI PENDIDIKAN KECAKAPAN HIDUP PADA PENDIDIKAN LUAR SEKOLAH
}

\author{
Sofyan Hadi, Yoyon Suryono \\ Institut Agama Islam Negeri (IAIN) Jember, Universitas Negeri Yogyakarta \\ hadi_sofy@yahoo.com,yoyonsuryono@yahoo.com
}

\begin{abstract}
Abstrak
Penelitian ini bertujuan untuk mengembangkan model evaluasi penyelenggaraan pendidikan life skills. Model pengembangan yang digunakan adalah research and development yang dikembangkan Borg dan Gall dengan pendekatan kuantitatif. Prosedur pengembangan dipetakan menjadi tahap pra-pengembangan, pengembangan, dan penerapan model. Berdasarkan hasil penelitian dapat disimpulkan (1) Model evaluasi life skills education (ELSEd) meliputi komponen input, proses, dan hasil pendidikan life skills, (2) Evaluasi model ELSEd memiliki kepekaan yang baik terhadap objek yang diteliti dan mengungkap data yang dihasilkan, (3) Tingkat koherensi instrument ELSEd sesuai dengan rancangan, (4) Karakteristik Model ELSEd berbeda dengan evaluasi model lain, (5) Reliabilitas butir ketiga komponen evaluasi bernilai antara 0,826 - 0,975 dan validitas konstruk untuk semua komponen pada model ELSEd ini diketahui nilai chi square sebesar: 4,188-191,686; p-value: 0,063-0,241; dan nilai RMSEA: 0,029-0,076. Oleh karena nilai p-value lebih besar dari 0,05 dan RMSEA kurang dari 0,08 maka dapat dinyatakan bahwa model Life Skills Education (ELSEd) adalah cocok dan fit, (6) Kelebihan model ELSEd yaitu komprehensif, sederhana, fleksibel, efektif, dan life skills oriented.
\end{abstract}

Kata kunci: pengembangan, model, evaluasi, program, life skills, Pendidikan Luar Sekolah

\section{DEVELOPING AN EVALUATION MODEL OF LIFE SKILLS PROGRAM OF NON FORMAL EDUCATION}

\author{
Sofyan Hadi, Yoyon Suryono \\ Institut Agama Islam Negeri (IAIN) Jember, Universitas Negeri Yogyakarta \\ hadi_sofy@yahoo.com,yoyonsuryono@yahoo.com
}

\begin{abstract}
This study aims to develop an evaluation model of life skills education. The development model used is research and development which is developed by Borg and Gall by using a quantitative approach. The development procedure is mapped into the pre-development, development, and application of the model. Based on the results of this study, it can be concluded that: (1) Evaluation model of life skills education (ELSEd) includes component inputs, processes, and result of life skills education, (2) The ELSEd Evaluation models have a good sensitivity to the object under study and reveal the resulted data, (3) the level of coherence of the ELSEd instrument is in accordance with the design, (4) Characteristics of ELSEd models are different from other models of evaluation, (5) The item reliability of the three evaluation components are between 0.826 to 0.975 and construct validity for all components in ELSEd model are chi square value of : 4.188 to 191.686; $\mathrm{p}$ - value : 0.063 to 0.241; and the value of RMSEA: 0.029 to 0.076 . Therefore, p-value is bigger than 0.05 and RMSEA is less than 0.08 , it can be stated that the model of Life Skills Education (ELSEd) is suitable and fit, (6) The advantages of ELSEd models are comprehensive, simple, flexible, effective, and life skills oriented.
\end{abstract}

Keywords: development, model, evaluation, program, life skills, Non Formal Education 


\section{Pendahuluan}

Banyak para pakar, badan, maupun lembaga yang memiliki kompetensi dan otoritas di bidang diklat dan kesehatan memberikan pengertian tentang konsep “Life Skills". WHO (Ditjen Diklusepa, 2003, p.6) memberikan pengertian bahwa Life Skills adalah berbagai keterampilan/kemampuan untuk dapat beradaptasi dan berperilaku positif, yang memungkinkan seseorang mampu menghadapi berbagai tuntutan dan tantangan dalam hidupnya seharihari secara efektif. Broling (1989) mendefinisikan Life Skills sebagai suatu interaksi dari berbagai pengetahuan dan kecakapan yang sangat penting untuk dimiliki oleh seseorang sehingga mereka dapat hidup mandiri dan mengelompokkan Life Skills ke dalam tiga kelompok kecakapan, yaitu (1) kecakapan hidup sehari-hari (daily living skill); (2) kecakapan pribadi/sosial (personall social skill); dan (3) kecakapan untuk bekerja (occupational skill). Kecakapan hidup seharihari (daily living skill), meliputi kecakapan dalam pengelolaan kebutuhan pribadi, pengelolaan keuangan pribadi, pengelolaan rumah pribadi, kesadaran kesehatan, kesadaran keamanan, pengelolaan makanangizi, pengelolaan pakaian, tanggungjawab sebagai warga negara, pengelolaan waktu luang, rekreasi, dan kesadaran lingkungan. Kecakapan pribadi/sosial (personal/social skill), meliputi keasadaran diri (minat, bakat, sikap, kecakapan), percaya diri, komunikasi dengan orang lain, tenggang rasa dan kepedulian pada sesama, hubungan antarpersonal, pemahaman dan pemecahan masalah, menemukan dan mengembangkan kebiasaan positif, kemandirian dan kepemimpinan. Kecakapan untuk bekerja (occupational skill), meliputi kecakapan dalam pemilihan pekerjaan, perencanaan kerja, persiapan keterampilan kerja, pelatihan keterampilan, penguasaan kompetensi, kemampuan menjalankan suatu profesi, kesadaran untuk menguasai berbagai keterampilan, kemampuan menguasai dan menerapkan teknologi, merancang dan melaksanakan proses pekerjaan, dan menghasilkan produk barang maupun jasa. Depdiknas sepakat dengan WHO (Ditjen Diklusepa, 2003, p.6) yang mengelompokkan Life Skills atau kecakapan hidup ke dalam lima aspek, yaitu:

(1) kecakapan mengenal diri (self awareness) yang juga sering disebut kecakapan personal (personal skill); (2) kecakapan berpikir rasional (thinking skill); (3) kecakapan sosial (social skill) atau sering juga disebut kecakapan antar personal (interpersonal skill); (4) kecakapan akademik (academic skill) yang sering pula disebut kemampuan berpikir ilmiah (scientific method); dan (5) kecakapan vokasional (vocational skill).

Kecakapan mengenal diri (self awareness) atau kecakapan personal (personal skill) mencakup (1) penghayatan diri sebagai makhluk Tuhan Yang Maha Esa, anggota masyarakat dan warga negara, serta (2) menyadari dan mensyukuri kelebihan dan kekurangan yang dimiliki, sekaligus menjadikannya sebagai modal dalam meningkatkan dirinya sebagai individu yang bermanfaat bagi diri sendiri dan lingkungannya. Kecakapan berpikir rasional (thinking skill) mencakup (1) kecakapan menggali dan menemukan informasi (information searching); (2) kecakapan mengolah informasi dan mengambil keputusan (information processing and decision making skills); serta (3) kecakapan memecahkan masalah secara kreatif (creative problem solving skill). Kecakapan sosial (social skill) atau kecakapan antar personal (interpersonal skill) mencakup (1) kecakapan komunikasi dengan empati (communication skill); dan (2) kecakapan bekerjasama (collaboration skill). Tiga kecakapan hidup ini dapat dikategorikan sebagai General Life Skill (GLS) atau kecakapan hidup yang bersifat umum atau kecakapan hidup generik, yaitu kecakapan hidup yang diperlukan oleh setiap orang, baik yang sudah bekerja, belum/ tidak bekerja maupun mereka yang sedang menempuh diklat terlepas diklat formal, informal maupun non formal.

Pengelompokan Life Skills atau kecakapan hidup di atas, dapat diperjelas melalui sebuah skema sebagaimana disajikan pada Gambar 1. 


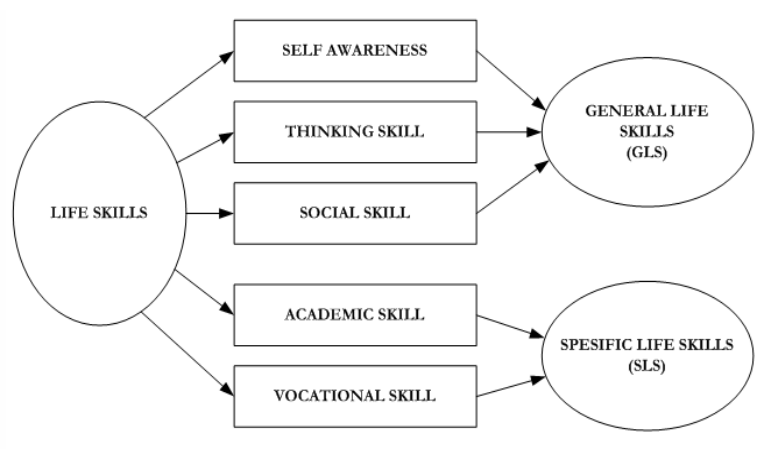

Gambar 1. Skema Pengelompokan Kecakapan Hidup (Life Skills)

Menurut Joint commitee on standards for educational evaluation dalam jurnal Unesco (1993, P.12) "program evaluation is evaluation that assess educational activities which provide service on a continuing basis and often involve curricular offerings". Evaluasi program merupakan evaluasi yang menilai aktivitas di bidang diklat dengan menyediakan data yang berkelanjutan. Dengan demikian, evaluasi program merupakan rangkain kegiatan yang dilakukan dengan sengaja dan secara cermat untuk mengetahui tingkat keterlaksanaan atau keberhasilan program dengan cara mengetahui keefektifan masing-masing komponennya, baik terhadap program yang sedang berjalan maupun program yang telah berlalu. Evaluasi program biasanya dilakukan untuk kepentingan pengambilan keputusan dalam rangka menentukan kebijakan selanjutnya. Melalui evaluasi, suatu program dapat dilakukan penilaian secara sistematik, rinci dan menggunakan prosedur yang sudah diuji secara cermat. Dengan metode tertentu akan diperoleh data yang handal, dapat dipercaya sehingga penentuan kebijakan akan tepat, dengan catatan data yang diguakan sebagai dasar pertimbangan ter-sebut adalah data yang tepat, baik dari segi isi, cakupan, maupun tepat dari segi waktu penyampaian (Issac, S., \& Michael, W.B. 1979, p.78-80).

Tujuan evaluasi program adalah menyediakan informasi sebagai dasar dalam pengambilan keputusan, penyusunan kebijakan maupun penyusunan program-program selanjutnya. Keputusan dapat terkait dengan program yang sedang berjalan dan menentukan bahwa program tersebut perlu diperbaiki, dihentikan atau dilanjutkan. Agar keputusan kebijakan maupun pogram yang disusun dapat berjalan efektif, informasi yang lengkap, akurat, dan tepat waktu mutlak diperlukan. Model Evaluasi Life Skills Education/ELSEd merupakan suatu model yang diharapkan dapat memenuhi kebutuhan tersebut terkait dengan program pendidikan Life Skills di pendidikan formal dan non formal juga informal, selanjutnya peneliti sebut dengan PLS. Model ELSEd didasarkan asumsi bahwa evaluasi program pendidikan Life Skills di tingkat PLS tidak cukup hanya mencakup output atau hasil belajar peserta semata, namun perlu mencakup input serta proses pembelajaran. Hal ini perlu dilakukan karena bagaimanapun juga dalam setiap program, output program selalu dipengaruhi oleh input serta proses pelaksanaan program itu sendiri. Penilaian terhadap output pendidikan Life Skills tidak hanya meliputi aspek Kecakapan Akademik saja tetapi juga mencakup penilaian terhadap Kecakapan Personal, Kecakapan Sosial, dan Kecakapan Vokasi peserta program. Hal ini sesuai dengan tujuan pendidikan Life Skills PLS. Model ELSEd menggunakan pendekatan evaluasi input, proses, serta hasil. Model ELSEd merupakan kombinasi model CIPP (Context, Input, Process, and Product) dari Stufflebeam (Stufflebeam, D.L. \& Shinfield, A.J. 1985, pp.34-37) dan Kirkpatrick (Kirkpatrick, D.L 1998, pp.7576), evaluation model (The four levels).

Dari uraian tersebut, penelitian ini bertujuan untuk mengembangkan model evaluasi penyelenggaraan pendidikan life skills.

\section{Metode Penelitian}

Penelitian ini merupakan penelitian pengembangan (Research and Development). Borg and Gall (1989, p.782) mengemukakan bahwa model penelitian dan pengembangan adalah a process used develop and validate educational product. Secara konseptual dan prosedural, model pengembangan yang digunakan sebagai kajian pada penelitian dan pengembangan ini mengacu pada model Borg and Gall dengan memodifikasi 10

Pengembangan Model Evaluasi Pendidikan Kecakapan - 263 Sofyan Hadi, Yoyon Suryono 
(sepuluh) tahapan penelitian menjadi 4 (empat) tahap penelitian, yang pada intinya sama melalui langkah-langkah Borg and Gall tersebut. Demikian juga dengan penentuan jumlah subjek uji coba mengacu pada model Borg and Gall, yakni jumlah subjek uji coba dari pertama, kedua dan seterusnya semakin meningkat. Borg and Gall memberikan rujukan kepada peneliti bahwa untuk melakukan penelitian pengembangan, ditempatkan sepuluh langkah utama sebagai berikut.

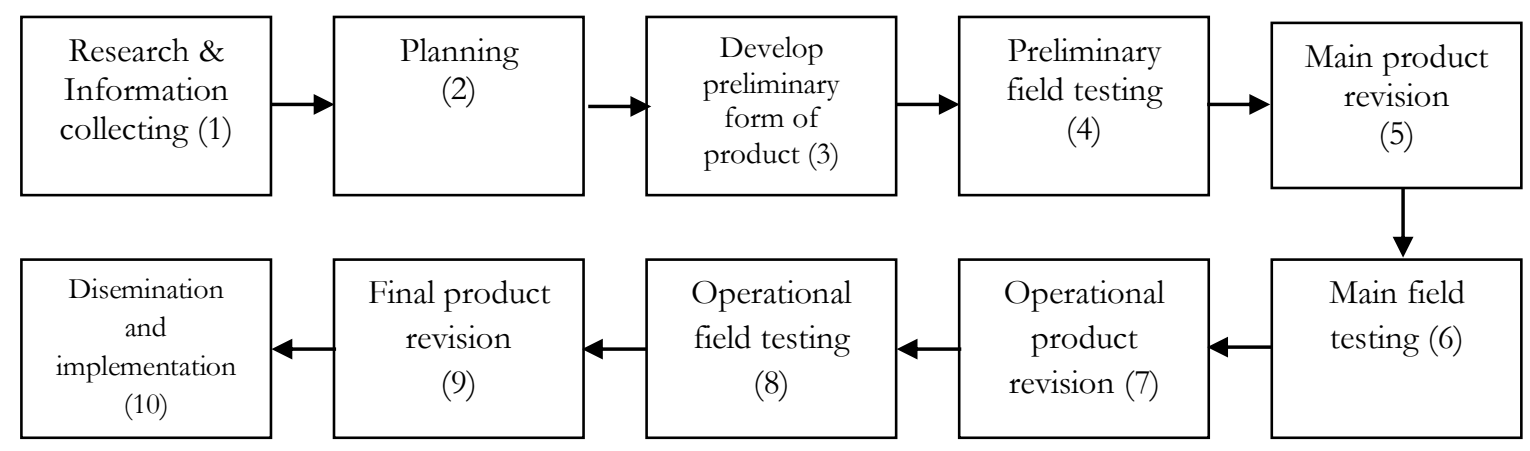

Gambar 2. Model R \& D Borg and Gall

Model ELSEd mempunyai tiga komponen, yaitu evaluasi input pembelajaran life skills terdiri dari tiga komponen, yakni materi, sarana pembelajaran, dan motivasi, kualitas proses pembelajaran life skills terdiri dari komponen kinerja tutor life skills, metode pembelajaran, iklim kelas, dan sikap siswa, sedangkan hasil pembelajaran life skills terdiri dari empat komponen yakni kecakapan akademik, personal, sosial, dan vokasi. Komponen-komponen tersebut disajikan dalam bagan pada Gambar 3.

Subjek Uji coba atau responden yang terlibat dalam penelitian ini terdiri dari Pengelola, instruktur, serta kepala dinas pendidikan masyarakat, sebagai representasi dari pimpinan lembaga penyelenggara life skills dan mahasiswa PEP S3. Pemilihan subjek uji coba pada masing-masing tahap didasarkan karakteristik dan jumlah subjek ujicoba. Beberapa asumsi yang yang melandasi pemikiran bahwa pengembangan model evaluasi cukup dilakukan tiga tahap, yaitu a) peningkatan ragam dan jumlah subjek ujicoba sebanyak tiga kali diharapkan dapat menjangkau seluruh ragam karakteristik, PLS, warga belajar maupun pendamping/pemantau yang ada dalam lingkungan Jember; b) dengan terwakilinya seluruh ragam karakteristik PLS mulai dari PLS di kota maupun di pedesaan dengan karakteristik pengelola maupun peserta juga lingkungan tempat pelaksanaan program life skills dapat diperoleh sebuah model yang baik, maka diasumsikan bahwa model tersebut dapat diterapkan untuk semua klasifikasi dan karakteristik PLS. Secara lebih terperinci, penyebaran subjek uji coba dapat dilihat pada Tabel 1.

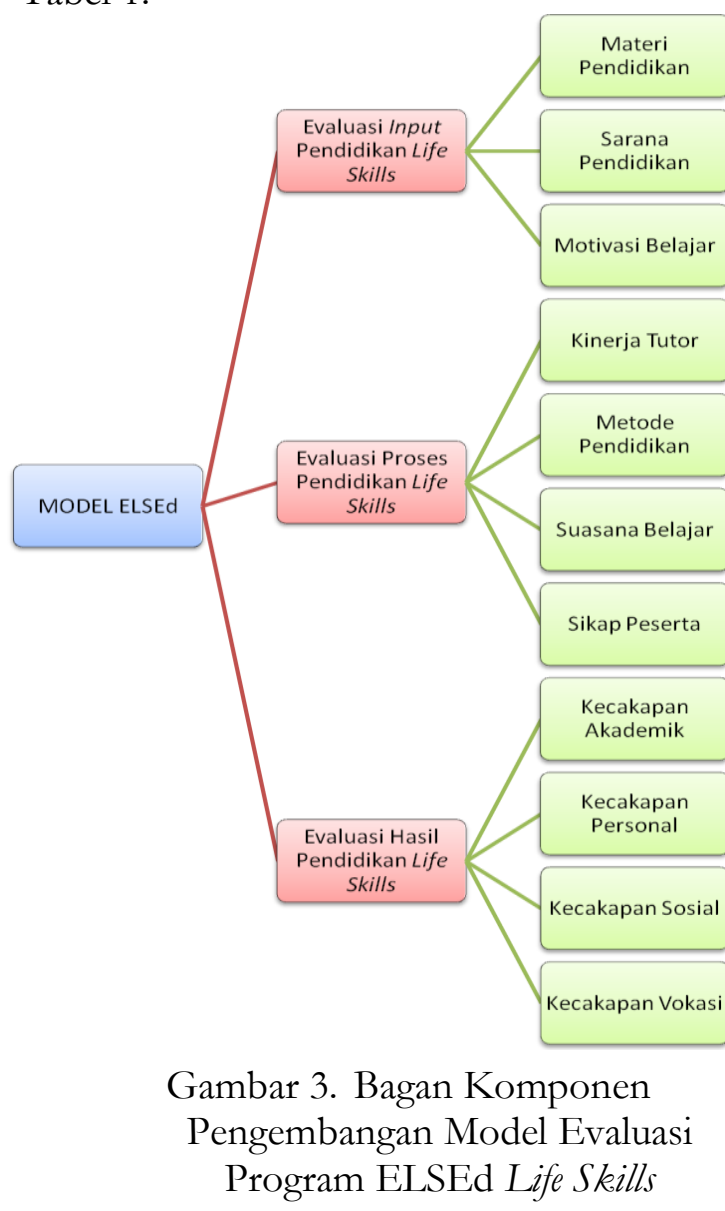


Tabel 1. Subjek Coba Model Life skills Education (ELSEd)

\begin{tabular}{lcccc}
\hline \multirow{2}{*}{ Subjek Uji Coba } & \multicolumn{3}{c}{ Uji Coba ke } & Jumlah \\
\cline { 2 - 4 } & I & II & III & Total \\
\hline Kepala Lembaga & 1 & 1 & 3 & 5 \\
Tutor & 2 & 2 & 6 & 10 \\
Peserta Program & - & 70 & 282 & 352 \\
\hline \multicolumn{1}{c}{ Jumlah } & 3 & 73 & 291 & 367 \\
\hline
\end{tabular}

\section{Hasil Penelitian dan Pembahasan}

Evaluasi model ELSEd disusun berdasarkan analisis bahwa input, proses, dan hasil pembelajaran life skills mempunyai pengaruh terhadap hasil pembelajaran. Evaluasi input meliputi: materi pendidikan, sarana prasarana pendidikan dan motivasi belajar peserta didik, sedangkan proses dipengaruhi oleh kinerja tutor, metode pendidikan, iklim belajar dan sikap peserta pembelajaran life skills. Sedangkan hasil dari pembelajaran life skills tersebut diharapkan peserta didik mempunyai 4 (empat) kecakapan yaitu: kecakapan akademik, kecakapan personal, kecakapan sosial dan kecakapan vokasi.

Kemudian untuk menguji kecocokan atau kesesuaian antara model teoretis dengan data empiris, baik model pengukuran maupun model evaluasi dalam penelitian ini didasarkan pada empat indikator, yaitu: 1) Chi-Square, 2) Significance Probability; 3) Root Mean Square Error of Approximation (RMSEA); dan 4) Goodness of Fit Index (GFI). Adapun standar besarnya nilai indikator disajikan pada Tabel 2.

Tabel 2. Goodness of Fit Index

\begin{tabular}{ccl}
\hline $\begin{array}{l}\text { Goodness of } \\
\text { fit index }\end{array}$ & Cut of Value & \multicolumn{1}{c}{ Keterangan } \\
\hline Chi Square & $\begin{array}{c}\text { Diharapkan } \\
\text { kecil }\end{array}$ & $\begin{array}{l}\text { Untuk } \mathrm{n}=100->200 ; \\
\text { model baik bilamana cbi- } \\
\text { square dengan derajat } \\
\text { bebas-nya tidak jauh } \\
\text { berbeda }\end{array}$ \\
\begin{tabular}{ccl} 
Significance & $\geq 0,05$ & Digunakan untuk n besar \\
Probability & & Mirip $\mathrm{R}^{2}$ dalam regresi \\
RMSEA & $\leq 0,08$ & \\
GFI & $\geq 0,90$ & \\
\hline
\end{tabular}
\end{tabular}

Untuk menjawab rumusan masalah tentang model evaluasi pendidikan life skills yang dapat memberikan informasi yang tepat dan akurat bagi pimpinan lembaga dan tutor serta bermanfaat secara optimal bagi pelaksanaan pendidikan life skills di PLS, digunakan teknik analisis deskriptif dengan persentase, rerata skor (mean), dan analisis kualitatif dengan model interaktif. Pelaksanaan Research and Development (R\&D) melalui kajian teoretik, temuan empirik dan praktik di lapangan sebagai draft awal konsep, dilanjutkan dengan diskusi panel dengan pakar pendidikan dan praktisi pendidikan menyebabkan komposisi komponen dan indikator banyak mengalami perubahan mendasar.

Selanjutnya, peneliti melakukan kajian teoretik dan empirik ulang secara intensif dengan promotor disertasi yang hasilnya digunakan sebagai draft awal atau bahan untuk FGD dan seminar instrumen terbatas. Pelaksanaan FGD secara intensif dan efektif, menemukan dan menetapkan konsep kualitas dan hasil pendidikan life skills. Sebelum model diujicobakan pada subjek coba, seluruh instrumen beserta perangkatnya telah divalidasi oleh para pakar dan praktisi pendidikan life skills melalui uji coba pendahuluan terhadap 16 ahli yang terdiri atas dosen pendidikan life skills (4 orang), kepala lembaga (4 orang), tutor life skills (4 orang), dan ahli evaluasi (4 orang).

Setelah uji coba pendahuluan, model dan instrumen diperbaiki untuk selanjutnya dilakukan uji coba operasional. Uji coba operasional dilakukan secara purposive sampling, dengan berbagai pertimbangan tertentu yakni kualitas lembaga yang dapat mewakili informasi dan kelengkapan program. Uji coba operasional ini dilakukan di UPT-PK Jember yang memiliki kualitas sangat baik, SKB Bondowoso yang berkualitas baik, LKP Prospektif College yang berkualitas sedang/menengah, dan PKBM As-Syifa Jember yang berkualitas kurang baik. Berikut dijelaskan secara sistematis data uji coba lapangan tahap pertama, tahap kedua, dan tahap ketiga sebagai hasil penelitian pengembangan. 
Keterbacaan Instrumen Input Pendidikan Life Skills

Rangkuman rerata hasil keterbacaan instrumen Input pada ketiga uji coba disajikan pada Tabel 3.

Pada penilaian ketiga tahap tersebut menunjukkan bahwa rerata skor total hasil penilaian mengalami peningkatan dari rerata 3,78 menjadi 4,00 dan yang terakhir, yaitu 4,13 pada tahap ketiga. Adanya peningkatan rerata skor tersebut menunjukkan bahwa ada korelasi yang positif dengan revisi yang dilakukan sebelumnya.

Tabel 3. Rekapitulasi Hasil Uji Keterbacaan Instrumen Input Pendidikan Life Skills

\begin{tabular}{ccccccccccccc}
\hline \multirow{2}{*}{ Tahap } & $\Sigma$ & \multicolumn{10}{c}{ Rerata Skor Butir } & \multirow{2}{*}{ Rerata } \\
\cline { 2 - 10 } & Resp & 1 & 2 & 3 & 4 & 5 & 6 & 7 & 8 & 9 & 10 & \\
\hline 1 & 16 & 3,63 & 3,44 & 3,5 & 3,69 & 3,66 & 3,94 & 4,19 & 3,81 & 4,14 & 3,88 & 3,78 \\
2 & 75 & 3,89 & 3,98 & 4,14 & 4,05 & 3,93 & 4,07 & 4,02 & 4,09 & 3,98 & 4,02 & 4,00 \\
3 & 97 & 4,2 & 3,93 & 4,18 & 4,32 & 4,22 & 4,07 & 4,02 & 4,09 & 4,31 & 4,02 & 4,13 \\
\hline
\end{tabular}

Keterbacaan Instrumen Proses Pendidikan Life Skills

Rangkuman rerata keterbacaan proses pendidikan life skills di PLS disajikan pada Tabel 4.

Pada penilaian ketiga tahap tersebut, rerata skor total hasil penilaian mengalami peningkatan dari rerata 3,80 menjadi 4,04 dan yang terakhir 4,14 pada uji coba ketiga. Adanya peningkatan rerata skor tersebut menunjukkan bahwa ada korelasi yang positif dengan revisi yang dilakukan sebelumnya.

Tabel 4. Rekapitulasi Hasil Uji Keterbacaan Instrumen Input Pendidikan Life Skills

\begin{tabular}{cccccccccccccc}
\hline Tahap & $\Sigma$ & \multicolumn{1}{c}{ Rerata Skor Butir } & \multirow{1}{*}{ Rerata } \\
\cline { 2 - 10 } & Resp & 1 & 2 & 3 & 4 & 5 & 6 & 7 & 8 & 9 & 10 & 11 & \\
\hline 1 & 16 & 3,69 & 4,00 & 3,63 & 3,5 & 4,00 & 3,63 & 4,06 & 4,06 & 3,69 & 3,88 & 3,69 & 3,80 \\
2 & 75 & 3,93 & 4,02 & 3,95 & 4,18 & 4,07 & 4,03 & 4,05 & 4,01 & 4,01 & 4,06 & 4,11 & 4,04 \\
3 & 97 & 4,2 & 4,26 & 4,14 & 4,19 & 4,11 & 3,93 & 4,07 & 4,02 & 4,09 & 4,44 & 4,13 & 4,14 \\
\hline
\end{tabular}

Keterbacaan Instrumen Hasil Pembelajaran

Rangkuman rerata keterbacaan instrumen hasil penilaian pada ketiga uji coba disajikan pada Tabel 5 .

Rerata skor total hasil penilaian ketiga tahap mengalami peningkatan dari rerata
3,80 menjadi 4,00 dan yang terakhir pada tahap ketiga mencapai nilai rata-rata 4,16. Peningkatan tersebut belum maksimal, karena hasil penilaian tersebut masih dalam klasifikasi baik.

Tabel 5. Rekapitulasi Hasil Uji Keterbacaan Instrumen Hasil Pendidikan Life Skills

\begin{tabular}{ccccccccccccccc}
\hline Tahap & $\Sigma$ & \multicolumn{1}{c}{ Rerata Skor Butir } & Rerata \\
\cline { 2 - 11 } & Resp & 1 & 2 & 3 & 4 & 5 & 6 & 7 & 8 & 9 & 10 & 11 & \\
\hline 1 & 16 & 3,56 & 4,00 & 3,75 & 3,75 & 3,69 & 4,00 & 3,69 & 3,75 & 3,81 & 3,81 & 3,94 & 3,80 \\
2 & 75 & 4,04 & 4,07 & 3,98 & 3,87 & 3,98 & 3,98 & 4,06 & 3,97 & 4,02 & 4,02 & 4,04 & 4,00 \\
3 & 97 & 4,15 & 3,99 & 3,96 & 4,06 & 4,05 & 3,92 & 4,11 & 3,95 & 4,54 & 4,56 & 4,45 & 4,16 \\
\hline
\end{tabular}




\section{Model Evaluasi}

Berdasarkan hasil penilaian pada ketiga tahap uji coba terhadap Model ELSEd, ditemukan rerata skor yang termasuk dalam klasifikasi baik, sehingga model ini baik untuk digunakan di Pendidikan Non For- mal Informal. Berdasarkan hasil analisis tersebut menunjukkan bahwa evaluasi Model ELSED beserta perangkatnya memiliki sifat objektivitas, praktibalitas, dan efisiensi atau ekonomis yang cukup baik.

Tabel 6. Rekapitulasi Hasil Penilaian Model Evaluasi

\begin{tabular}{ccccccccccc}
\hline Tahap & Jumlah & \multicolumn{1}{c}{ Rerata Skor Butir } & Rerata \\
\cline { 2 - 9 } & Resp & 1 & 2 & 3 & 4 & 5 & 6 & 7 & 8 & Skor \\
\hline 1 & 16 & 3,56 & 3,88 & 3,81 & 3,81 & 4,13 & 3,94 & 3,88 & 3,88 & 3.79 \\
2 & 22 & 4,00 & 3,78 & 4,00 & 3,91 & 4,09 & 3,70 & 4,04 & 3,70 & 3.90 \\
3 & 31 & 4,00 & 4,06 & 4,32 & 3,97 & 3,77 & 4,00 & 4,52 & 4,16 & 4.10 \\
\hline
\end{tabular}

Panduan Evaluasi

Berdasarkan hasil penilaian ketiga uji coba terhadap panduan evaluasi didapatkan rerata skor seperti disajikan pada Tabel 7 .

Mengacu pada standar penilaian, maka rerata skor tersebut menunjukkan bahwa panduan evaluasi masuk pada kategori baik dan dapat digunakan tanpa harus direvisi terlebih dahulu. Peningkatan nilai rerata tersebut mulai dari tahap pertama hingga ketiga adalah 3,74, 4,02, dan 4,20. Peningkatan tersebut menunjukkan bahwa hasil perbaikan setelah tahap pertama memiliki makna pada semakin baiknya panduan evaluasi.

Tabel 7. Rekapitulasi Hasil Penilaian Panduan Evaluasi

\begin{tabular}{|c|c|c|c|c|c|c|c|c|c|}
\hline \multirow[t]{2}{*}{ Tahap } & \multirow{2}{*}{$\begin{array}{c}\text { Jumlah } \\
\text { Resp }\end{array}$} & \multicolumn{7}{|c|}{ Rerata Skor Butir } & \multirow{2}{*}{$\begin{array}{c}\text { Rerata } \\
\text { Skor }\end{array}$} \\
\hline & & 1 & 2 & 3 & 4 & 5 & 6 & 7 & \\
\hline 1 & 16 & 3,63 & 4 & 3,63 & 3,81 & 3,56 & 3,93 & 3,63 & 3,74 \\
\hline 2 & 23 & 3,78 & 4,30 & 3,91 & 3,83 & 4,13 & 4,17 & 4,04 & 4,02 \\
\hline 3 & 31 & 4,42 & 4,48 & 4,06 & 4,35 & 3,87 & 4,06 & 4,13 & 4,20 \\
\hline
\end{tabular}

Validitas dan Reliabilitas

Rangkuman perhitungan normalitas dapat dilihat pada Tabel 8.

Sementara mengacu pada hasil analisis LISREL dengan menggunakan teknik CFA (Confirmatory Factor Analysis), menunjukkan bahwa semua nomor butir instrumen baik instrumen kualitas (kinerja tutor, materi pelajaran pendidikan life skills, metode pembelajaran, sarana pembelajaran, sikap peserta didik dan motivasi belajar pendidikan life skills maupun instrumen hasil pembelajaran (kecakapan akademik, personal dan sosial), memiliki t muatan faktor lebih dari 1,96 sebagai batas minimal validitas butir instrumen. Dengan demikian seluruh instrumen dapat dikatakan valid. Rangkuman nilai chi-square, df, P-Value, dan RMSEA disajikan pada Tabel 9. 
Tabel 8. Rangkuman Tingkat Reliabilitas Instrumen

\begin{tabular}{clcc}
\hline Instrumen & $\begin{array}{c}\text { Uji Coba Kedua } \\
\text { (UPT-PK Jember) }\end{array}$ & $\begin{array}{c}\text { Uji Coba Ketiga } \\
\text { (SKB Bondowoso, LPK Prospective College } \\
\text { Jember, dan PKBM As-syifa Jember) }\end{array}$ \\
\hline Input & Materi & 0,975 & 0,936 \\
& Sarpras & 0,932 & 0,888 \\
& Motivasi & 0,954 & 0,957 \\
\hline Proses & Kinerja & 0,957 & 0,948 \\
& Metode & 0,945 & 0,948 \\
& Iklim & 0,958 & 0,946 \\
& Sikap & 0,948 & 0,918 \\
\hline \multirow{2}{*}{ Hasil } & Akademik & 0,901 & 0,826 \\
& Personal & 0,883 & 0,924 \\
& Sosial & 0,954 & 0,932 \\
& Vokasi & 0,895 & 0,893 \\
\hline
\end{tabular}

Tabel 9. Nilai Chi-square, df, P-Value, dan RMSEA

\begin{tabular}{clcccc}
\hline & & Chi-square & Df & P-Value & RMSEA \\
\hline \multirow{2}{*}{ Input } & Materi & 90,572 & 77 & 0,1072 & 0,062 \\
& Sarpras & 70,838 & 54 & 0,173 & 0,069 \\
& Motivasi & 191,686 & 230 & 0,093 & 0,048 \\
\hline \multirow{2}{*}{ Proses } & Kinerja & 216,397 & 252 & 0,0627 & 0,018 \\
& Metode & 78,811 & 65 & 0,142 & 0,076 \\
& Iklim & 155,88 & 152 & 0,072 & 0,053 \\
& Sikap & 28,422 & 27 & 0,135 & 0,029 \\
\hline \multirow{2}{*}{ Hasil } & Akademik & 4,188 & 5 & 0,063 & 0,054 \\
& Personal & 36,559 & 35 & 0,0718 & 0,038 \\
& Sosial & 42,624 & 35 & 0,241 & 0,031 \\
& Vokasi & 20,111 & 14 & 0,097 & 0,035 \\
\hline
\end{tabular}

Hasil analisis LISREL dengan teknik Confirmatory Factor Analysis (CFA) untuk semua konstruk model Life Skills Education (ELSEd) diperoleh nilai chi square sebesar: 4,188-191,686; p-value: 0,063-0,241; dan nilai RMSEA: 0,029-0,076. Oleh karena nilai $\mathrm{p}$-value lebih besar dari 0,05 dan RMSEA kurang dari 0,08 maka dapat dinyatakan bahwa model Life Skills Education (ELSEd) adalah cocok dan fit.
Hasil Uji Coba Utama di UPT-PK Jember

Hasil analisis deskriptif terhadap angket peserta didik, tutor dan pimpinan lembaga secara keseluruhan hasil penilaian responden terhadap implementasi komponen input, proses, dan hasil pendidikan life skills di PLS dipaparkan pada Tabel 10 berikut. 


\section{Hasil Penilaian Peserta didik}

Tabel 10. Hasil Penilaian Peserta didik terhadap Implementasi Komponen dan Indikator Input, Proses, dan Hasil Pendidikan Life Skills di UPT-PK Jember

\begin{tabular}{lllcl}
\hline No & \multicolumn{1}{c}{ Komponen } & & Rerata Skor & Klasifikasi \\
\hline & & Input & & \\
1 & Materi pendidikan life skills & & 3,80 & Baik \\
2 & Sarana pendidikan life skills & & 3,95 & Baik \\
3 & Motivasi Belajar Peserta didik & & 3,78 & Baik \\
& & Rata-rata & 3,84 & Baik \\
\hline & & Proses & & \\
1 & Kinerja Tutor & & 3,68 & Baik \\
2 & Metode pembelajaran life skills & & 3,84 & Baik \\
3 & Iklim Kelas & & 3,82 & Baik \\
4 & Sikap Peserta didik & & 2,84 & Baik \\
& & Rata-rata & 3,55 & Baik \\
\hline \multirow{2}{*}{1} & Akademik & Hasil & & \\
2 & Personal & & 3,79 & Baik \\
3 & Sosial & & 3,91 & Baik \\
4 & Vokasi & & 3,62 & Baik \\
& & & 3,92 & Baik \\
\hline
\end{tabular}

\section{Hasil Penilaian Tutor}

Tabel 11. Hasil Penilaian Tutor terhadap Implementasi Komponen dan Indikator Input dan Proses Pendidikan Life Skills di UPT-PK Jember

\begin{tabular}{|c|c|c|c|c|}
\hline No & Komponen & & Rerata Skor & Klasifikasi \\
\hline \multicolumn{5}{|c|}{ Input } \\
\hline 1 & Materi pendidikan life skills & & 3,18 & Sangat Baik \\
\hline \multirow[t]{2}{*}{2} & Sarana pendidikan life skills & & 3,33 & Sangat Baik \\
\hline & & Rata-rata & 3,25 & Sangat Baik \\
\hline & & Proses & & \\
\hline 1 & Kinerja Tutor & & 3,64 & Sangat Baik \\
\hline \multirow[t]{2}{*}{2} & Metode pembelajaran life skills & & 3,56 & Sangat Baik \\
\hline & & Rata-rata & 3,6 & Sangat Baik \\
\hline
\end{tabular}

Hasil Penilaian Kepala Lembaga terbadap Kinerja Tutor Life skills

Berdasarkan hasil penilaian kepala lembaga terhadap kinerja tutor life skills di UPT-PK Jember menunjukkan bahwa kinerja tutor sudah baik, dengan rerata nilai 3,80 klasifikasi baik. Itu artinya bahwa kinerja tutor life skills dinilai oleh kepala lembaga sudah melaksanakan tugas dengan baik. Klasifikasi nilai yang diberikan oleh kepala lembaga terhadap komponen kualitas tutor sama dengan nilai yang diberikan peserta pelatihan, yaitu baik. 


\section{Uji Coba Ketiga (Operasional)}

\section{SKB Bondowoso}

\section{Hasil Penilaian Peserta didik}

Tabel 12. Hasil Penilaian Peserta didik terhadap Implementasi Komponen dan Indikator Input, Proses, dan Hasil Pendidikan Life Skills di SKB Kab. Bondowoso

\begin{tabular}{|c|c|c|c|c|}
\hline No & Komponen & & Rerata Skor & Klasifikasi \\
\hline & & Input & & \\
\hline 1 & Materi pendidikan life skills & & 3,90 & Baik \\
\hline 2 & Sarana pendidikan life skills & & 3,80 & Baik \\
\hline \multirow[t]{2}{*}{3} & Motivasi Belajar Peserta didik & & 3,84 & Baik \\
\hline & & Rata-rata & 3,85 & Baik \\
\hline & & Proses & & \\
\hline 1 & Kinerja Tutor & & 3,87 & Baik \\
\hline 2 & Metode pembelajaran life skills & & 3,91 & Baik \\
\hline 3 & Iklim Kelas & & 4,02 & Baik \\
\hline \multirow[t]{2}{*}{4} & Sikap Peserta didik & & 3,68 & Baik \\
\hline & & Rata-rata & 3,87 & Baik \\
\hline & & Hasil & & \\
\hline 1 & Akademik & & 3,93 & Baik \\
\hline 2 & Personal & & 3,85 & Baik \\
\hline 3 & Sosial & & 3,97 & Baik \\
\hline \multirow[t]{2}{*}{4} & Vokasi & & 3,95 & Baik \\
\hline & & Rata-rata & 3,93 & Baik \\
\hline
\end{tabular}

\section{Hasil Penilaian Tutor}

Tabel 13. Hasil Penilaian Tutor terhadap Implementasi Komponen dan Indikator Input dan Proses Pendidikan Life Skills di SKB Kab. Bondowoso

\begin{tabular}{lllcc}
\hline No & \multicolumn{1}{c}{ Komponen } & & Rerata Skor & Klasifikasi \\
\hline \multirow{2}{*}{1} & Materi pendidikan life skills & Input & & \\
2 & Sarana pendidikan life skills & & 3,86 & Baik \\
& & Rata-rata & 3,83 & Baik \\
& & Proses & Baik \\
\hline \multirow{2}{*}{1} & Kinerja Tutor & & 3,71 & Baik \\
2 & Metode pembelajaran life skills & & 4,00 & Baik \\
& & Rata-rata & 3,86 & Baik \\
\hline
\end{tabular}

Hasil Penilaian Kepala Lembaga terbadap Kinerja

\section{Tutor Life Skills}

Penilaian kepala lembaga mengenai kinerja tutor pendidikan life skills di SKB Kabupaten Bondowoso menunjukkan bahwa kinerja tutor pendidikan life skills memiliki rerata nilai 4,00. Nilai rerata yang diperoleh tersebut termasuk dalam klasifikasi baik. Ini menunjukkan bahwa tutor pendidikan life skills di PLS ini dinilai oleh kepala lembaga telah mampu melaksanakan tugas secara baik dalam pelaksanaan pendidikan life skills. Hasil penilaian kepala lembaga tersebut sama dengan penilaian kinerja tutor yang dilaksanakan oleh para tutor dan peserta didik. Tidak terdapat perbedaan kedua jenis penilaian tersebut, karena hasil ketiga penilaian termasuk dalam klasifikasi baik. Bila dilihat dari nilai yang 
diperoleh, penilaian kinerja tutor oleh tutor memiliki nilai yang lebih sedikit dibandingkan dengan penilaian oleh peserta didik dan kepala lembaga, sedangkan hasil penilaian yang paling besar dihasilkan oleh

\section{LPK Prospective College Jember}

\section{Hasil Penilaian Peserta Didik}

Tabel 14. Hasil Penilaian Peserta didik terhadap Implementasi Komponen Input, proses dan Hasil Pendidikan Life Skills di LPK Prospective College Jember

\begin{tabular}{|c|c|c|c|c|}
\hline No & Komponen & & Rerata Skor & Klasifikasi \\
\hline & & Input & & \\
\hline 1 & Materi pendidikan life skills & & 3,76 & Baik \\
\hline 2 & Sarana pendidikan life skills & & 4,00 & Baik \\
\hline \multirow[t]{2}{*}{3} & Motivasi Belajar Peserta didik & & 3,8 & Baik \\
\hline & & Rata-rata & 3,85 & Baik \\
\hline & & Proses & & \\
\hline 1 & Kinerja Tutor & & 3,84 & Baik \\
\hline 2 & Metode pembelajaran life skills & & 3,93 & Baik \\
\hline 3 & Iklim Kelas & & 3,84 & Baik \\
\hline \multirow[t]{2}{*}{4} & Sikap Peserta didik & & 4,08 & Baik \\
\hline & & Rata-rata & 3,92 & Baik \\
\hline & & Hasil & & \\
\hline 1 & Akademik & & 4,02 & Baik \\
\hline 2 & Personal & & 3,98 & Baik \\
\hline 3 & Sosial & & 4,01 & Baik \\
\hline \multirow[t]{2}{*}{4} & Vokasi & & 4,02 & Baik \\
\hline & & Rata-rata & 4,00 & Baik \\
\hline
\end{tabular}

\section{Hasil Penilaian Tutor}

Tabel 15. Hasil Penilaian Tutor terhadap Implementasi Komponen dan Indikator Input dan Proses Pendidikan Life Skills di LPK Prospective College Jember

\begin{tabular}{cllcc}
\hline No & \multicolumn{1}{c}{ Komponen } & & Rerata Skor & Klasifikasi \\
\hline \multirow{2}{*}{1} & Materi pendidikan life skills & Input & & \\
2 & Sarana pendidikan life skills & & 3,95 & Baik \\
& & Rata-rata & 3,83 & Baik \\
& & Proses & Baik \\
\hline \multirow{2}{*}{1} & Kinerja Tutor & & 3,75 & Baik \\
2 & Metode pembelajaran life skills & & 4,00 & Baik \\
& & Rata-rata & 3,84 & Baik \\
\hline
\end{tabular}

Hasil Penilaian Kepala Lembaga terhadap Kinerja Tutor Pendidikan Life Skills

Hasil penilaian kepala lembaga terhadap kinerja tutor pendidikan life skills di LPK Prospective College Jember meng- kelapa lembaga. Secara berurutan, hasil penilaian kinerja tutor pendidikan life skills yang dinilai oleh tutor, peserta didik, dan kepala lembaga adalah 3,87, 3,71, dan 4,00. 
laksanakan tugas dalam kegiatan pembelajaran pendidikan life skills dengan kategori cukup. Nilai dari Kepala Lembaga sama dengan penilaian peserta didik dan tutor, yang sama-sama termasuk dalam kategori PKBM As-Syifa Jember

Hasil Penilaian Peserta didik

Tabel 16. Hasil Penilaian Peserta didik terhadap Implementasi Komponen dan Indikator Input, Proses, dan Hasil Pendidikan Life Skills di PKBM As-Syifa Jember

\begin{tabular}{cllcc}
\hline No & \multicolumn{1}{c}{ Komponen } & Rerata Skor & Klasifikasi \\
\hline & & Input & & \\
1 & Materi pendidikan life skills & & 4,06 & Baik \\
2 & Sarana pendidikan life skills & & 4,02 & Baik \\
3 & Motivasi Belajar Peserta didik & & 3,89 & Baik \\
& & Rata-rata & 2,37 & Baik \\
\hline & & Proses & & \\
1 & Kinerja Tutor & & 3,58 & Baik \\
2 & Metode pembelajaran life skills & & 3,93 & Baik \\
3 & Iklim Kelas & & 3,92 & Baik \\
4 & Sikap Peserta didik & & 3,80 & Baik \\
& & Rata-rata & 3,88 & Baik \\
\hline \multirow{2}{*}{1} & Akademik & Hasil & & \\
2 & Personal & & 4,12 & Baik \\
3 & Sosial & & 3,94 & Baik \\
4 & Vokasi & & 3,90 & Baik \\
& & & 4,04 & Baik \\
\hline
\end{tabular}

\section{Hasil Penilaian Tutor}

Tabel 17. Hasil Penilaian Tutor terhadap Implementasi Komponen dan Indikator Kualitas Pendidikan Life Skills di PKBM As-Syifa Jember

\begin{tabular}{clccc}
\hline No & \multicolumn{1}{c}{ Komponen } & Rerata Skor & Klasifikasi \\
\hline \multirow{2}{*}{1} & Materi pendidikan life skills & Input & & \\
2 & Sarana pendidikan life skills & & 3,77 & Baik \\
& & & 3,96 & Baik \\
& & 3,86 & Baik \\
\hline \multirow{2}{*}{1} & Kinerja Tutor & Proses & & \\
2 & Metode pembelajaran life skills & & 3,82 & Baik \\
& & 3,72 & Baik \\
& & 7,54 & Baik \\
\hline
\end{tabular}

Hasil Penilaian Kepala Lembaga terhadap Kinerja Tutor Life Skills

Penilaian kepala lembaga mengenai kinerja tutor PKH di PKBM As-Syifa cukup. Secara berurutan, hasil rerata penilaian tutor yang dilaksanakan oleh peserta didik, tutor, dan kepala lembaga adalah 3,84, 3,75, dan 3,01. 
pendidikan life skills di PLS ini dinilai baik oleh kepala lembaga dan dianggap belum dapat melaksanakan tugas dalam kegiatan pendidikan life skills dengan baik.

\section{Uji Normalitas}

Uji asumsi normalitas dalam penelitian ini menggunakan uji normalitas dari Kolmogorov-Smirov dengan bantuan software SPSS for Windows. Pengujian didasarkan pada nilai signifikansi (sig) pada output SPSS dengan kriteria pengujiannya adalah apabila nilai sig $\geq 0,05$, menunjukkan data berdistribusi normal, sedangkan apabila nilai sig $<0,05$, menunjukkan bahwa data tidak berdistribusi normal. Berdasarkan analisis menggunakan SPSS for Windows 17.00 diperoleh kesimpulan bahwa data kualitas pendidikan life skills dan hasil pembelajaran berdistribusi normal.
Tabel 18. Uji Normalitas

\begin{tabular}{lc}
\hline Kinerja & $\begin{array}{c}\text { Uji Coba } \\
\text { Operasional }\end{array}$ \\
Materi & 0,147 \\
Metode & 0,091 \\
Sarpras & 0,053 \\
Iklim & 0,054 \\
Sikap & 0,087 \\
Motivasi & 0,057 \\
Kecakapan Akademik & 0,068 \\
Kecakapan Personal & 0,076 \\
Kecakapan Sosial & 0,068 \\
Kecakapan Vokasi & 0,061 \\
\hline
\end{tabular}

Tingkat Ketercapaian Implementasi Komponen ELSEd

Adapun tingkat ketercapaian implementasi komponen model ELSEd (Evaluasi Kualitas dan Output Pendidikan Life Skills) di PLS dapat disajikan sebagai berikut.

Tabel 19. Tingkat Ketercapaian Implementasi Model ELSEd

\begin{tabular}{|c|c|c|c|c|c|c|c|c|c|}
\hline \multirow[t]{2}{*}{ No } & \multirow[t]{2}{*}{$\begin{array}{c}\text { Aspek } \\
\text { Penilaian }\end{array}$} & \multicolumn{2}{|c|}{$\begin{array}{l}\text { UPT-PK } \\
\text { Jember }\end{array}$} & \multicolumn{2}{|c|}{$\begin{array}{c}\text { SKB } \\
\text { Bondowoso }\end{array}$} & \multicolumn{2}{|c|}{$\begin{array}{l}\text { LKP Prospective } \\
\text { College Jember }\end{array}$} & \multicolumn{2}{|c|}{$\begin{array}{l}\text { PKBM Asy- } \\
\text { Syifa Jember }\end{array}$} \\
\hline & & Nilai & Ket. & Nilai & Ket. & Nilai & Ket. & Nilai & Ket. \\
\hline \multicolumn{10}{|c|}{ INPUT } \\
\hline 1 & Materi pendidikan & 4,21 & $\mathrm{SB}$ & 3,90 & B & 3,21 & $\mathrm{C}$ & 2,51 & K \\
\hline 2 & Sarana pendidikan & 4,39 & SB & 3,80 & B & 3,30 & $\mathrm{C}$ & 2,39 & K \\
\hline 3 & Motivasi Belajar Peserta didik & 4,20 & SB & 3,84 & B & 3,20 & $\mathrm{C}$ & 2,20 & K \\
\hline \multicolumn{10}{|c|}{ PROSES } \\
\hline 4 & Kinerja Tutor & 4,40 & SB & 3,87 & B & 3,33 & $\mathrm{C}$ & 2,39 & $\mathrm{~K}$ \\
\hline 5 & Metode pembelajaran & 4,23 & SB & 3,91 & B & 3,12 & $\mathrm{C}$ & 2,23 & K \\
\hline 6 & Iklim Kelas & 4,43 & SB & 4,02 & B & 3,31 & $\mathrm{C}$ & 2,43 & K \\
\hline 7 & Sikap Peserta didik & 4,21 & SB & 3,68 & B & 3,27 & $\mathrm{C}$ & 2,21 & K \\
\hline \multicolumn{10}{|c|}{ HASIL } \\
\hline 8 & Kecakapan Akademik & 4,31 & SB & 3,93 & B & 3,21 & $\mathrm{C}$ & 2,31 & K \\
\hline 8 & Kecakapan Personal & 4,22 & SB & 3,85 & B & 3,39 & $\mathrm{C}$ & 2,22 & K \\
\hline 9 & Kecakapan Sosial & 4,32 & SB & 3,97 & B & 3,11 & $\mathrm{C}$ & 2,32 & $\mathrm{~K}$ \\
\hline 10 & Kecakapan Vokasi & 4,44 & SB & 3,95 & B & 3,32 & $\mathrm{C}$ & 2,44 & K \\
\hline
\end{tabular}

SK=Sangat Kurang; $\mathrm{K}=$ Kurang; $\mathrm{C}=$ Cukup; $\mathrm{B}=\mathrm{Baik}$; $\mathrm{B}=$ Sangat Baik

Berdasarkan analisis statistik deskriptif di atas, menunjukkan bahwa peserta didik UPT-PK Jember dalam pelaksanaan program pendidikan life skills lebih baik jika dibandingkan dengan lembaga lain dan secara berurutan dibawahnya adalah SKB Bondowoso, LKP Prospective College Jember, dan PKBM Asy-Syifa Jember. Data ini didukung pula oleh temuan hasil observasi, wawancara dan dokumen yang menunjuk- kan bahwa ketiga lembaga tersebut memiliki klasifikasi yang demikian adanya.

\section{Simpulan}

Berdasarkan pada hasil penelitian dan pengembangan yang dilakukan, melalui proses pengumpulan dan analisis data, dapat dikemukakan kesimpulan penelitian sebagai berikut. 
1. Model evaluasi pendidikan life skills mengukur tiga komponen, yaitu komponen input, proses, serta hasil pendidikan life skills.

2. Komponen input pembelajaran life skills terdiri dari tiga indikator, yakni materi, sarana pembelajaran, dan motivasi, Komponen proses pembelajaran life skills terdiri dari empat indikator yakni kinerja tutor life skills, metode pembelajaran, iklim kelas, dan sikap peserta didik, sedangkan hasil pembelajaran life skills terdiri dari empat komponen yakni kecakapan akademik, personal, sosial, dan vokasi;

3. Evaluasi model ELSEd hasil penelitian dan pengembangan ini memiliki kepekaan yang baik terhadap objek yang diteliti;

4. Tingkat koherensi instrumen ELSEd ketika digunakan untuk menilai input, proses, serta hasil pembelajaran life skills sesuai dengan rancangan.

5. Reliabilitas butir instrumen input, proses maupun hasil di empat lembaga baik di UPT-PK Jember, SKB Bondowoso, LKP Prospektif Collegge Jember dan PKBM Asy-syifa Jember dengan teknik Cronbach Alpha antara 0,826 - 0,975, kemudian validitas untuk semua konstruk model ELSEd nilai chi-square sebesar: 4,188191,686; p-value: 0,063-0,241; dan nilai RMSEA: 0,029-0,076. Oleh karena nilai p-value lebih besar dari 0,05 dan RMSEA kurang dari 0,08 maka dapat dinyatakan bahwa model Life Skills Education (ELSEd) adalah cocok dan fit .

6. Model ELSEd memiliki beberapa karakteristik yang membedakan dengan evaluasi model lain, yakni (a) model digunakan untuk mengevaluasi pelaksanaan pembelajaran life skills di lembaga non formal, (b) tidak tergantung pada pendekatan pembelajaran tertentu yang dilaksanakan oleh tutor, (c) komprehensif (mengevaluasi kualitas imput, proses sekaligus hasil pembelajaran life skills), (d) dapat digunakan sebagai evaluasi diagnostik (diagnostic evaluation) untuk menemukan dan memetakan berbagai aspek dalam pembelajaran life skills di lembaga non formal yang lain (input, proses maupun hasil pembelajaran life skills) yang perlu diperbaiki, dan (e) bersifat terbuka untuk dikembangkan lebih lanjut

7. Kelebihan model ELSEd dalam proses implementasi di lembaga yaitu komprehensif, fleksibel, efektif, dan berorientasi pada pendidikan kecakapan hidup.

\section{Daftar Pustaka}

Borg, W.R. \& Gall, M.D. (1983). Educational research $\left(4^{\text {th }}\right.$ ed). New York: Longman.

Broling, D.E (1989). Life centered career education: A Competency-based approach. (3th ed). Reston Va: The council for exceptional children.

Ditjen Diklusepa. (2002). Hasil-hasil monitoring terpadu program PLSP dan PKPS BBM (PPD-PSE dan life skills). Disampaikan pada temu Evaluasi program PLSP tahun 2002 tanggal 16 Nopember 2002 di Solo.

(2002). Pedoman umum pelaksanaan program pendidikan berorientasi keterampilan bidup (life skills) melalui pendekatan broad based education (BBE) dalam bidang pendidikan luar sekolah dan pemuda. Jakarta: Ditjen Diklusepa Depdiknas.

Ditjen Diklusepa. (2002). Petunjuk teknis penyelenggaraan keterampilan bidup di $S K B$, Jakarta: Ditjen Diklusepa Depdiknas.

Ditjen Diklusepa. (2003). Pedoman penyelenggaraan program keterampilan bidup (life skills) Pendidikan Luar Sekolah. Jakarta: Ditjen Diklusepa Depdiknas.

Issac, S., \& Michael, W.B. (1979). Handbook in research and evaluation. San Diego: Edits Publisher.

Kirkpatrick, D.L (1998). Evaluating training programs: The four levels (2nd ed). San Fransisco: Berret-Koehler Publisher, Inc.

Stufflebeam, D.L. \& Shinfield, A.J. (1985). Systematic evaluation. Boston: Kluwer Nijhof Publishing.

Unesco. (1993). Principal regional office for Asia and the pacific, ATPL-CE Volume I, Continuing Education: New Policies and Directions. Bangkok: Unesco. 